\title{
The Commonwealth Approach to Atlantic Warfare, 1945-55
}

\section{Norman Friedman}

Il s'agit d'une analyse de la manière dont les marines du Commonwealth (Canada et Australie) ont coopéré avec la Marine royale britannique pour aborder les problèmes de l'après-guerre de 1945, en particulier la guerre anti-sous-marine dans l'Atlantique. Du point de vue britannique, la coopération a fait suite à une approche coopérative navale antérieure, qui avait fonctionné avec succès pendant la guerre, reflétant en pratique une Marine d'empire commune. Compte tenu de la nouvelle réalité des armes nucléaires, la Marine royale britannique s'est aussi intéressé à la production dans ces deux pays du Commonwealth, donné que la base de la production en Royaume-Uni pourrait être gravement endommagée. Il $y$ avait également un intérêt dans le développement coopératif de technologies clés, y compris la DATAR canadienne (système de télémétrie d'acquisition et de poursuite des données), et les frégates de première génération d'après-guerre (classe St Laurent de la Marine royale canadienne par rapport au type 12 britannique). Surplombant cette histoire de 1945-55 est le rôle des États-Unis et ses propres espoirs de créer une approche de la Marine d'empire envisagé par la Marine royale britannique depuis avant 1914.

This essay is an analysis of the way in which Commonwealth navies (principally Canada) cooperated with the Royal Navy in approaching the post-World War II antisubmarine warfare (ASW) problem. From the British point of view, such cooperation continued an earlier cooperative naval approach, which had worked successfully during World War II, and which had been adopted in place of the Empire Navy approach the Admiralty favored beginning well before 1914. From a U.S. perspective, the Commonwealth approach to naval cooperation is of great interest because it suggests how the cooperative initiative the U.S. Navy now favors might work.

\section{Empire Navy versus Commonwealth Navies}

This Commonwealth story is part of a larger empire and Commonwealth story, which seems to be little appreciated. By 1900, and probably much earlier, the British had come to see their empire much more as a voluntary entity than other European empires. About that time a senior Admiralty official commented that whether individual governments stayed in the empire depended on what they got out of it, in trade and in

The Northern Mariner/Le marin du nord XXIV, Nos. 3 \& 4 (Jul. \& Oct. 2014), 195-213 Canadian Military History 23, Nos. 3 \& 4 (Summer \& Autumn 2014), 195-213 
defensive terms. He meant local "white" governments, not the locals they ruled, but his comment can be contrasted with the typical view of continental European imperialists: that they were seizing property for the home government (many of the British clearly saw their empire the same way, but its fundamental character was different). To the extent that this perception was widely shared within the United Kingdom, it can probably be traced back to the British failure to suppress the American Revolution.

Shadowing the formal empire was an informal one, comprising countries or territories whose governments supported the British, and often gave them preferential trade terms. ${ }^{1}$ In return, the British, and mainly the Royal Navy, provided a degree of security those governments valued. For example, by the 1920s much of China could be considered part of the informal empire, and British investments in China were an important source of revenue at home. The Japanese invasion of Manchuria in 1931 directly threatened the United Kingdom, because the Japanese made it clear that they wanted a monopoly over Manchuria, and that they planned to eject Britain (and all other Westerners) from the Far East. That the presence of a powerful British China Fleet did not deter the Japanese in any way also badly damaged the informal empire. On the other hand, much earlier the existence of the British fleet did deter the Spanish from seeking to overthrow the new South American republics after 1821, and countries like Argentina and Chile became part of the informal empire. So did the United States: the Monroe Doctrine (1823) worked because the Royal Navy in effect enforced it.

What the home country offered was protected global trade. The great issue in imperial defense was how to protect both that trade and the territories of the empire, all major parts of which (except India) could be approached by a potential enemy only by sea. Local politicians naturally emphasized local territorial defense, but the Admiralty tried hard, at least from about 1901 onwards, to convince them that control of the sea was far more important. If the empire controlled the sea, no enemy power would dare invade major colonies. At the same time, control of the sea (assuming that could be achieved) would protect the trade which nourished all parts of the empire. The practical meaning of these terms changed with technology and with the world political situation. However,

1 The idea of informal empire is developed in P.J. Cain and A.G. Hopkins, British Imperialism 1688-2000 (London: Longman, 2000 [second edition; first edition 1993]). Much of the formal empire seems to have been obtained to support the trading requirements of the informal empire. Places like Hong Kong were valuable as trading ports, not in themselves. The British (or at least some of them) seem to have been unique among nineteenth and early twentieth century Europeans in widely accepting the modern idea that investment and return were what counted, not physical control; hence many modern claims that conquest does not pay. Of course it was well understood that control of some territory made it more attractive for informal empire partners to work with the British. The idea of informal empire seems particularly relevant to the current position of the United States and its various partners. If the United States is considered part of the informal British Empire of the past, there is much more continuity in post-1945 imperial history than is generally imagined. From a defense point of view, the overwhelming problem of informal empire is that the imperial power has to convince its partners to contribute to the common defense, since they know that it is in the imperial power's interest to defend them whether or not they contribute. 
there were generally real differences in the outlooks of the local governments of the major territories.

The Australian and New Zealand governments clearly saw the sea and seaborne trade as essential to their existence. By 1909 they also tended to see Japan as the main local threat; it was relatively difficult to convince them that a German threat to the United Kingdom in Europe directly affected them. For India, whatever the state of a British understanding or alliance with Russia, the main threat was a Russian thrust across the Himalayas. During World War I the government of India was willing to support empire sea power by seizing strategic territory in places like the Red Sea and the Gulf, but it showed no real interest in financing a Royal Indian Navy. Like India, Canada was mainly land-oriented, aware of earlier land threats mounted by the United States. The Canadian government wanted to help the British with naval support, but the Canadian Parliament tended not to agree, at least in peacetime. It took the World War I German Uboat campaign, mounted on both sides of the Atlantic, to demonstrate to the Canadian government that trade protection was a real issue. However, that realization faded after World War I, the young Royal Canadian Navy nearly being abolished. Canadian interest in a navy revived in the late 1930 s, probably because many Canadians became uncomfortably aware that U-boat warfare could come back. The Battle of the Atlantic during World War II was so powerful a lesson, and the post-war threat of the Soviets so obvious, that the Royal Canadian Navy faced no existential threat after 1945.

It was impossible for the Admiralty to force local empire governments to contribute to a common Empire Navy, even though it could make reasonable arguments that such an entity would be the most efficient way to protect the empire. One reason why was surely that local governments always suspected that the empire fleet would be somewhere else when they were attacked. The key argument for the Empire Navy was that seaborne trade was the lifeblood of the empire, not merely of the home country. Any threat to seaborne trade had to be dealt with, possibly far from those contributing to overall empire strength. Another reason dominion governments rejected the Empire Navy idea was almost certainly that they were unwilling to help defend the informal element of the empire, for example the British economic interest in China.

At the 1909 Imperial Conference the Admiralty asked each of the wealthy dominions and the Raj to contribute a fleet unit to a future Empire Pacific Fleet: a battlecruiser and several cruisers. Australia was the only taker (New Zealand contributed a battlecruiser to the Royal Navy). The great irony was that, although the Empire Navy was promoted from 1909 onwards mainly to deal with the Japanese threat to the empire, its chief component - the RAN - fought mainly in European waters during World War I. Canada considered buying capital ships and cruisers, but ultimately decided not to. It seems fair to imagine that Canadians did not consider any Japanese threat as seriously as did the Australians, and also that they doubted the United Kingdom would deal with the only threat that counted, that posed by the United States. The Empire Navy idea was revived after World War I, explicitly to deal with a Japanese threat which had been dramatized by hostile Japanese wartime behavior. As in the period before 1914, Australia made the greatest contribution. The RAN that developed between the world wars was 
designed mainly for commerce protection, to deal with the principal expected threat, surface raiders.

In 1920-21 the Admiralty began to assemble its primary inter-war war plan, in which a fleet would steam east to Singapore to prevent the Japanese from moving south. Initially the Admiralty hoped that the $\mathrm{RN}$ would provide the capital ships, while the Commonwealth nations would provide the trade protection cruisers (ideas changed after the Washington Conference did away with the capital ship program). ASW did not figure in discussions of empire naval defense, although the Royal Navy and its partners certainly continued to work on ASW measures. One reason they do not figure in the central policy documents of the time is that it was assumed that the large number of destroyers surviving from World War I would become available as convoy escorts. It also seems to have been assumed that sufficient asdic sets (sonars) could have been extemporized. ${ }^{2}$ Too, there seems to have been an assumption, at least in the Royal Navy, that the kind of commerce-destroying submarine warfare prosecuted by the Germans during World War I had been counter-productive, as it had helped bring the United States into the war.

The Royal Navy began to focus on anti-submarine warfare again after the 1930 London Naval Conference failed to ban submarines (while drastically cutting the empire destroyer force), but more in the Japanese context than in the European. The Germans did not openly begin building submarines until 1935, and crash escort production began only in 1938, in the aftermath of the Munich crisis - when, despite the "peace in our time" speech, the British ordered the emergency ships which would be useful only in wartime, such as corvettes and fast escorts. By that time the Canadians were becoming interested in ASW. However, the building programs of both the Australian and Canadian navies emphasized larger surface ships. For example, the RAN bought Tribal-class destroyers because they offered some cruiser characteristics, hence could help deal with future surface raiders. The big Australian corvette (actually large minesweeper) program came with the war. Similarly, the RCN began building corvettes only in 1939-40.

In September 1939, the Australian, Canadian, and New Zealand governments all joined with the British government to declare war against Germany, and all helped fight the Battle of the Atlantic. Canada made an enormous direct contribution in ships and men; the other Commonwealth countries contributed mainly men, such as specialist ASW officers. These countries were, and would remain after 1945, members of a loose but vital alliance. The informality of the alliance structure makes it difficult to understand, on a documentary level, when and why particular decisions were made post-war. Yet it is obvious that the navies felt related. Many years later it was common for Australian and

2 Quartz, the key material in asdic transducers, was stockpiled as an expendable, like ammunition. The 'Ten Year Rule' cut purchases of such expendables on the ground that it was assumed that war would not break out for a decade. Only later, after the rule had been cancelled and defense requirements redefined, did the time lag to produce the asdic sets came to figure in British planning. This is evident from the regular reports of the Defence Requirements Committee in Admiralty Board Minutes and Memoranda, United Kingdom National Archives (UKNA), ADM 167. 
Canadian officers to serve on board, and even to command, Royal Navy warships. Although each navy had had unique World War II experiences, all shared common tactical ideas and doctrines.

Probably the most important consequence of the shared wartime experience was a post-war fascination with ASW. In 1945 many in the Royal Navy might have said that their recent experience in the East Indies and with the U.S. Pacific Fleet had convinced them of the primacy of carrier operations, but far more British naval officers had spent the war in the Atlantic, fighting U-boats, and the Royal Navy and its allies emerged with a definite emphasis on ASW. Within the Commonwealth, work on anti-air warfare technology seems to have been limited to the United Kingdom.

Moreover, as the Soviet Union emerged after 1945 as the most likely future enemy, it was not difficult to argue that protecting trade (and territory) was far more important than attacking the Soviet surface fleet. The Soviet Union was poised to attack all the eastern Atlantic trade routes, and to seize territory from which to attack the vital trade through the Mediterranean to the Middle East and its oil. The Soviet threat is often equated simply to its large submarine fleet, but the Soviets also had a substantial landbased naval air arm. Anyone in the Royal Navy who had faced German land-based bombers while escorting convoys to Murmansk or the Mediterranean would take it quite seriously. There was also a Soviet surface fleet. Again, a Royal Navy which had been much affected by German surface units like the battleship Tirpitz would take this threat seriously, even though the Soviet surface navy had achieved nearly nothing during World War II. Americans whose view had been shaped by the Pacific, which was not a tradeprotection war (except for the failed attempts by the Japanese to protect their own trade), tended to emphasize the Soviet submarine fleet but not the other elements of Soviet naval power.

For the Royal Navy, the air and surface threats, more than the Soviet submarine threat, justified continued emphasis on carrier operations. Thus the Royal Navy emphasized the operation of high-performance fighters from its carriers. In the process it developed the important post-war carrier innovations, the steam catapult, the angled deck, and the optical landing sight. The U.S. Navy also emphasized carriers, but from a very different perspective. By 1945 it saw carriers more as strike weapons than as a means of gaining sea supremacy. It espoused a new generation of carriers specifically to operate heavy bombers, which were justified initially as a means of destroying the Soviet submarine force at its source (its bases). Heavy bombs would be needed because surely the Soviets, like the Germans of World War II, would protect their submarines in massive concrete pens. However, carrier-based heavy bombers offered all sorts of other options (in 1945 U.S. Navy planners pointed out that their aircraft could deliver about 60 percent as much tonnage as the land-based air force against Japan). The U.S. priorities show both in policy documents and in technical requirements for components such as catapults (and, for that matter, for aircraft). The Royal Navy was interested in such ideas; in 1949 it proposed to rebuild one or more carriers to mount nuclear strikes using heavy bombers. However, the Royal Air Force claimed a monopoly on strikes against land targets, and in the British Empire it thought it had enough bases to mount them against all important 
targets. At its insistence the British Joint Chiefs of Staff turned down the Royal Navy's proposal. $^{3}$ To the extent that British carriers were seen as ASW assets, that was because they had specialized ASW aircraft on board for tactical employment.

To understand what happened in post-war ASW it is important to understand that there are several very different approaches to such warfare. The history of ASW shows these approaches alternating over time, sometimes being tried in parallel, but usually not. The best-known approach is convoy: the ASW ships are concentrated with the submarines' targets, and the submarines reveal themselves by attacking. If there is some way of tracking submarines over a wide area, such as code-breaking or radio directionfinding, convoying (shipping control) makes it possible to divert ships from their likely attackers. Convoy diversion was extremely important in both world wars, but it is difficult to say how many ships it saved. The number of escorts depends on how many convoys are to be operated, that is, on the number of ships to be escorted. During World War I was discovered that larger convoys were more efficient than smaller ones, because the number of escorts rises proportional to the perimeter of the convoy, but the number of ships in the convoy rises as the area, which is proportional to the square of the perimeter. Even so, World War II experience and post-war studies generally showed that the West would need an extremely large number of convoy escorts in future conflicts.

A second, very different, approach is offensive ASW, for example by aircraft. If submarines can be located over a wide area, at least in theory it is more efficient to send out airplanes to attack them. During the two world wars, submarines (except those with snorkels) could not make good much distance except on the surface. Patrolling aircraft could, in effect, immobilize them. Once airplanes had radar, they could do so even at night. Initially sonobuoys were used to enable airplanes to attack submarines which dove as they approached (later they were used in conjunction with wide-area detection).

A third approach is to have submarines lie in wait in transit areas to attack enemy submarines as they passed through, either on the surface or, later, submerged at high (noisy) speed. This approach was more effective during World War I than World War II, because submarine detection was so difficult that alternatives were often ineffective. It was revived post-war.

A fourth and final approach is 'attack at source', an attempt to destroy enemy submarines in their bases. This idea initially justified the naval operation of heavy bombers during World War I. It was not successful at the time, and the Germans' use of

3 The U.S. Navy fought a protracted campaign against the U.S. Air Force to share scarce nuclear weapons, and it can be argued that 'attack at source' using such weapons was an argument deployed in hopes that the navy would ultimately gain a wider strategic role. In 1949 the United Kingdom was working on nuclear weapons, and the argument was more prospective. The Royal Navy obtained its first carrier-based nuclear bombs on the grounds that they were needed to attack Soviet surface raiders, but it is unclear whether that was particularly important. The key technical point was that by the mid-1950s bombs could be made small enough that large bombers and specially-designed carriers were no longer needed to deliver them, at least within a few hundred miles. The British papers are in UKNA, AIR 20/7209. 
submarine pens defeated it until very late in World War II. However, nuclear bombs later made it attractive. Air mining of areas near submarine bases was a variation on this theme, used with some success during World War II.

Without recognizing the variety of possibilities, it may seem that decisions to build, or not to build, particular kinds of ships are actually decisions about the priority accorded to ASW among other naval missions. The value (and practicality) of the different approaches varies over time (as technology changes) and also with operating areas. ASW is much too often simply equated with convoys and their escorts - partly because for so many British and Canadian naval officers, convoy was World War II ASW. Consequently it seemed that measures to mass-produce convoy escorts were the only practicable means of dealing with an emerging post-war Soviet submarine force.

It seems to have been very significant that, in the United Kingdom and the Commonwealth, air forces generally operated long-range ASW aircraft, even though those aircraft were under naval operational control (at least during World War II). By way of contrast, the U.S. Navy, and navies whose air arms it helped emerge (like those of post-war France and Germany) operated its own land-based ASW aircraft, to the extent that officers associated with such aircraft could rise to head ASW operations and development.

In all Western navies after 1945, it was assumed that the Soviets, who before World War II had the world's most numerous submarine fleet, would energetically pursue the new submarine technology created by the Germans: the snorkel (which allowed a submarine to operate entirely submerged), the fast diesel-electric submarine (Type XXI), and the faster closed-cycle submarine (Type XXVI). The snorkel dramatically reduced the value of the radar-equipped maritime patrol aircraft which, in combination with widearea surveillance (via code-breaking and HF/DF), had proven so effective during the war. However, new airborne radars could still detect periscopes, and conventional submarines equipped with snorkels were still relatively slow. Escorts could still deal with them as they tried to attack convoys, because they retained a significant speed advantage. The Type XXI, which could make about 17 knots submerged, was about as fast as wartime frigates in a seaway, and considerably faster than corvettes. Ideally, given wartime and early post-war ASW weapons, a successful escort had to be about ten knots faster than the submarine. The Type XXVI, capable of as much as 25 knots submerged for ten hours, was not yet ready in 1945 (there was some confusion as to how close it was to practicality), but it was generally accepted as the future threat. It was not at all clear that anyone could build an escort capable of 35 knots in a seaway. The expected Type XXVI equivalent never emerged, but nuclear submarines offered much the same performance on a sustained basis. They demanded longer-range sonars and longer-range weapons, including those on board helicopters which did have the required speed advantage.

The great lesson of World War II ASW was that it required very large numbers of convoy escorts. By 1950, for example, the U.S. Navy estimated that about 600 such ships would be needed in a future war. This number was derived, not from the estimated number of Soviet submarines, but from the estimated number of convoys which would have to be protected against any Soviet submarines which operated in the Atlantic. It 
happened that surviving wartime escorts and destroyers together provided much this number of ships, so the problem in 1950 seemed tractable. The disaster would come as the Soviets deployed fast submarines and anything short of a destroyer was no longer adequate. This problem was so serious that for a time the U.S. Navy planned to convert all surviving Fletcher-class destroyers (out of a class initially numbering 175) to escorts.

The enormous cost of an escort force created interest in alternative ways of dealing with the submarine threat. One, pursued by both the Royal Navy and the U.S. Navy, was to deploy their own submarines in the waters between Soviet submarine bases and the open oceans where the Soviets might attack convoys. Eventually that idea morphed into a combination of forward-deployed submarines and an air and surface barrier across the Greenland-Iceland-United Kingdom (GIUK) Gap, through which Soviet submarines would have to pass en route to their hunting ground in the North Atlantic.

Beginning about 1952 the U.S. Navy saw another kind of ASW emerge. Its scientists discovered that submarines could be tracked at very long range in the open Atlantic, using sea bottom sound receivers (they became the Sound Underwater Surveillance System, or SOSUS). Such tracking could be the basis of evasion by convoys (a very successful wartime tactic) and attack by maritime patrol aircraft. The waters around the British Isles were less amenable to long-range sound detection (a system called CORSAIR failed its tests at about the same time that SOSUS was succeeding). Too, the British and other Commonwealth countries were in a different position because their maritime patrol aircraft were operated not by their navies but by their air forces. In 1954 the Royal Air Force used the possibility of long-range sound detection and air prosecution of contacts as an argument against Royal Navy retention of aircraft carriers. The Canadian situation was also different, because the United States enlisted Canada to operate part of the SOSUS chain, in Canadian waters.

\section{Technical Cooperation and Development}

It is not clear to what extent an empire plan for integrated research and development was created during World War II. There was no such plan pre-war, because all empire naval R\&D was clearly concentrated in the United Kingdom. Just before the war the British revealed the secret radar technology to the major Commonwealth governments: Australia, Canada, New Zealand, and South Africa all began radar programs. During the war Canada in particular became involved in developing advanced types of naval radar (none of the other Commonwealth countries was as deeply involved in this particular type of radar). Some naval radar programs were transplanted to, or originated in, Canada: for example the Type 268 surface-search set and the Type 931 splash-spotting set for heavy surface gunnery. The products of these cooperative programs were intended mainly for the Royal Navy. Canada also had an integrated defense production plan with the United States, aircraft and presumably other equipment being produced in Canada specifically for U.S. use (and not for use by Canadian forces). Some wartime Canadian work, such as contributions to atomic research, clearly straddled the two alliances. 
It does not seem that much wartime empire radio or sonar development was conducted outside the United Kingdom.

Canada, Australia, and New Zealand all built wartime escorts. The Canadian program dwarfed the Australian and New Zealand programs, but the Australian ships were locally designed, unlike the Canadian ships. Both Canada and Australia also began local military aircraft production. The Australians, but not the Canadians, developed some of their own combat aircraft. In 1945 both governments wanted to develop local industries further. For example, the Australians wanted to build modern destroyers, manufacturing all or most of their components (the Canadian-built Tribal-class destroyers, undertaken for the same reasoning, were not completed until after the war).

Cooperative development apparently ended with the war. There was no question but that the Royal Navy was a welcome observer of what Canada and Australia developed, or that the British hoped that the Commonwealths would buy new British technology, but technology exchange was, it seems, generally on a commercial basis. For example, in 1949 development of the British Y-100 frigate steam power plant was accelerated specifically in hopes (which were justified) of selling it to Canada for the new Canadian frigate program, in competition with American machinery. Similarly, British officers visited Canada to examine the new DATAR digital combat system, which they realized was an alternative to their own analogue CAMBRIA.

On a deeper level, the reason these systems met requirements in several navies was that their originators drew on the World War II naval experience and on perceptions, formed in wartime, of what was needed. That meant the particular style of escortoriented ASW which had been so successful during the war.

For example, two Canadian naval officers conceived DATAR to meet a perceived requirement not yet set by the Royal Canadian Navy. ${ }^{4}$ They actively sought sponsorship, and initially received it from a private company, Ferranti of Canada (whose British branch was later responsible for British naval command and control systems). DATAR became an official Canadian program after Korean War mobilization released funds, and even then it suffered from insufficient funding. In retrospect it was extremely important. It demonstrated to the Royal Navy and to the U.S. Navy that a digital combat direction

$4 \quad$ For the DATAR story, see the author's Network-Centric Warfare: How Navies Learned to Fight Smarter in Three World Wars (Annapolis: Naval Institute Press, 2009). Documents on the Lamplight Conference and extensive accounts of the development of NTDS make clear the connection between DATAR and the U.S. system (too, many of those involved in DATAR made important contributions to the U.S. system). Unfortunately, British archives appear not to provide the basis for any comparable history of the British systems, ADA and ADAWS, which might show similar connections. Note that Ferranti was not the ADA/ADAWS system developer, but rather only the developer of their computers, and the British already had a combat direction system development team at the Admiralty Surface Weapons Establishment, which had developed the analogue CDS. Those involved seem to have concluded that the next-generation system would have to be digital without any input from North America, and some documents in First Sea Lord files suggest that the British considered their systems quite different from NTDS (they were more sophisticated and more automated, but unfortunately had less powerful computers). 
system, using a digital data link, was worthwhile (a prototype link was demonstrated between two Canadian minesweepers and a shore station). For the United States, the existence of DATAR as a successful working system justified the decision to develop NTDS, the key U.S. combat direction computer system for several decades, and the basis for several later systems. It is not clear to what extent the British Ferranti company was inspired by the DATAR experience to develop the computers the Royal Navy used for combat direction, or indeed to what (if any) extent DATAR inspired the development of the British digital systems. The British seem immediately to have decided on that basis to use a digital link (DPT) with their analogue combat direction system (CDS, of which CAMBRIA was a scaled-down version). In the 1950s the Royal Canadian Navy (and later the U.S. Navy) introduced an automatic NC-2 plotting table which may have been related to CAMBRIA.

Presumably late-war economics helped preclude continued close British and Canadian cooperation. During World War II Canada earned U.S. dollars and began to leave the sterling currency area to join the dollar area. That is why, in the late-1940s, the Royal Navy invested money to 'anglicize' the Canadian-developed Type 931 radar so that it could be produced in the United Kingdom. The British were badly deficient in dollars. For example, in 1952 they had to reject a Brazilian request for a substantial program of ship construction in British yards because the Brazilians expected to pay in pounds rather than in the dollars the British post-1945 economy badly needed. Australia was not in a currency position similar to Canada's, but on the other hand in 1945-55 it was not conducting major naval research (that came later, with Ikara, the Mulloka sonar, and with the Jindivik drone, among other things), hence it was not a good candidate for cooperative Anglo-Australian projects. The great exceptions were the Woomera missile range and Australian cooperation in British nuclear tests.

\section{Views of the Post-war World}

Beginning in 1944, the Admiralty developed plans for a post-war fleet. It did not envisage the sort of alliance structure which actually marked the post-war world, and at least explicitly it did not see the Soviet Union as a prospective enemy. Until about August 1947 its plans reflected the generic requirements of empire and Commonwealth defense, including an assumption that the two major naval dominions, Australia and Canada, would contribute forces. The force envisaged was built more around carriers and reaction groups of cruisers than anti-submarine ships. This was almost certainly the context in which the Admiralty encouraged the Royal Australian Navy and the Royal Canadian Navy to create their own Fleet Air Arms. To the extent that there was an explicit policy context, the immediate justification for naval forces seems to have been the enforcement role envisaged in the United Nations Charter, for which power projection forces were most relevant (postwar development of the French Navy involved a similar rationale). Although the mass of war-built British frigates was not discarded, the ships were laid up. Canada, which had built an enormous wartime ASW fleet, struck her corvettes and frigates, but did not sell all the frigates. It is not clear whether they were retained as a kind of emergency reserve; they were reinstated as the world situation changed. 
British naval planning through 1947 included considerable new construction, for example including large new cruisers. ${ }^{5}$ Beginning in 1947 the Admiralty had to accept that the British economy had been so badly damaged by the war that no such ambitious plans were practicable. The new construction program was pruned back to a few prototype frigates approved in 1945, and to the completion of major units, particularly carriers, laid down during the war. The existence of the latter made it possible for the Royal Navy to stave off a major structural crisis until the 1960s, when it became necessary to replace the carriers. The existence of a large war-built fleet also reduced the immediate effect of the post-war financial crisis. However, the operational British fleet shrank dramatically, as it was difficult to man, and at times even to fuel, the active ships.

Through 1945-46 there was a growing realization in Britain, Canada, and the United States that the Soviet Union was hostile. ${ }^{6}$ The assumption that the Royal Navy and the Commonwealth navies should build something like a modernized version of the pre-World War II fleet must have seemed less and less tenable in the face of a landoriented future enemy. In this context the main Royal Navy mission became sea control, which meant both open-ocean anti-submarine warfare and defense against land-based anti-shipping aircraft. The existence of the Royal Air Force blocked any alternative landattack mission. To the considerable extent that the major Commonwealth navies looked to the Royal Navy for leadership, its concentration on anti-submarine warfare shaped them. British naval plans of this period always included support by the main existing Commonwealth navies. It is not clear to what extent, if any, that included the new Commonwealth fleets being built by India and Pakistan.

Until about 1948 the official Royal Navy view was that it and the Commonwealth navies together could and should be strong enough to guarantee Commonwealth sea communications. That year the First Sea Lord was compelled to state publicly that he could no longer do so; the Commonwealth could not protect itself without an alliance with the United States. That came with NATO in 1949. However, through about 1955 the navy-to-navy relationship within the Commonwealth (particularly UK-Canada-Australia) was apparently much stronger than that between individual Commonwealth partners and the United States.

Given the likelihood that the United Kingdom itself would be badly damaged by Soviet attack in any future war, the British became interested in Australia as a rear production area, where the necessary fleet of escorts might be built. British shipyards had been damaged by German air attacks during the war, and post-war the British became interested in dispersing production so that ships spent minimum time on the slip. To

5 UKNA, ADM 167/129, Admiralty Board Minutes and Memoranda for 1947.

6 In each case, the military considered the Soviet Union the most likely future opponent by the end of the Second World War, but governments as a whole took much longer to adopt this view. Stalin was regarded as suspicious and unfriendly, but amenable to a combination of pressure and friendliness. For example, in 1947 the British were still willing to sell the Soviets advanced jet engines (the U.S. government was furious). The first attempt to form an anti-Soviet alliance, the Western Union, came only in 1948, at the time that Stalin took clearly hostile steps in the form of the Czech coup and the Berlin Blockade. 
some extent such ideas were probably inspired by the German program to build Type XXI submarines in exactly this way, to overcome the effect of allied bombing (the German program was fairly successful). It seems likely that Canada was not considered a potential rear production area, because any future nuclear war would feature a Soviet attack on the United States and on Canada, which was even closer to Soviet bomber bases.

In the late-1940s and early-1950s, British policy envisaged a possible World War III breaking out some time after 1957. By 1948 the British planned to modernize their forces, including the Royal Navy, to be ready for 1957 as a 'year of maximum danger' (a concept first tried in the 1930s, with 1939 as the target year). ${ }^{7}$ This reasoning was based on the expectation that Stalin would not move until he had repaired the considerable damage done by World War II (about five years) and then modernized his forces (another five years). It also seemed unlikely that Stalin would mount any kind of attack until he had enough atomic bombs to devastate the United States (it would take far fewer to deal with the United Kingdom, but that would not be enough). The 1957 date seems to have been based in part on an assumption that the Soviets would not have an atomic bomb until 1952. The U.S. government initially adopted the British assumption, but moved the date back to 1954 when the Soviets unexpectedly exploded their first nuclear bomb in 1949.

In this context, NATO was created as a deterrent to further Soviet expansion. Armies on the Continent were built up with U.S.-supplied World War II surplus weapons. These armies were relatively large, and they could easily absorb the new equipment. The hope was that modernizing them would provide enough strength to withstand any sudden Soviet land attack (which was considered relatively unlikely, given the U.S. nuclear deterrent). New naval building concentrated on the one area in which the large remaining war-built fleets were grossly deficient, mine warfare against influence mines (existing sweepers had excessive magnetic signatures). To the extent that new escorts wee needed, both the Royal Navy and the U.S. Navy saw in war-built destroyers the potential for numerous relatively inexpensive escorts. As in the case of submarines, this option was not available to Canada, which had only a small destroyer force (and much of it worn out by war's end), nor Australia, which at any rate was not a formal member of NATO. At this stage NATO was not a military alliance, and there was no serious attempt to require the NATO countries to make specific contributions to alliance military power.

The outbreak of war in Korea in June 1950 dramatically changed the situation. Many saw the Soviet-supported attack in Korea as a prelude to a World War III. It was shocking that Stalin seemed willing to risk nuclear war; the deterrent had failed. It now seems that Stalin was well aware of how small the U.S. nuclear stockpile was, and that he thought he was facing a closing window of opportunity. He seems not to have been aware of the extent to which the United States had mobilized nuclear production after the 1948 Czech coup, the event which had convinced so many in the West of Soviet hostility.

7 UKNA, ADM 116/5966. The ten-year period was set by the Chiefs of Staff in a 1947 paper on future defense policy. 
Given the threat of a Soviet attack in Europe, NATO was transformed into a military alliance with a war planning function. War plans, at least at the level of agreed doctrine, had to be agreed by all the governments in the Alliance. Over time, the U.S. government (and probably others) sought to change NATO doctrine to reflect radical shifts in its own thinking. At Lisbon in 1952 the NATO governments pledged to provide set levels of forces (generally not met) and to increase their military spending to match. The set levels included the large number of escorts a convoy ASW strategy demanded. Conversely, many navies within NATO, including both the Canadians and later the Royal Navy, justified their force goals to their own governments by reference to the agreed NATO goals, which were difficult to change. NATO goals were often, in effect, a substitute for independent force planning. The need to convince all the Alliance governments introduced considerable inertia. Thus the shape of forces developed at the major Lisbon conference did not change much for many years. Security concerns may also have been involved. For example, it seems unlikely that most NATO governments were ever informed of the role of submarines in forward areas beyond the GreenlandIceland-UK Gap. Similarly, it seems unlikely that, for many years, many NATO governments were informed of the role of SOSUS in cueing ASW forces. There is little evidence that the U.S. Navy tried to sell its new ASW strategies to the allies. ${ }^{8}$

The outbreak of war in Korea caught the British far short of the modernized force they wanted. The British government decided to mobilize. It discovered to its horror that its economy had not recovered sufficiently from the devastation of World War II. The naval side of mobilization was mass escort production. The program soon had to be pruned back. The British Chiefs of Staff began to ask whether the sort of all-out mobilization they had planned was really appropriate. Within a few years, that reopened

8 Unfortunately, available U.S. and British records give little idea of the extent to which changing U.S. ideas were discussed within NATO. There is evidence that most allies received only limited information. For example, French records of the Conseil Supérieure de la Marine, the senior body which advised the navy minister, show that in the mid-1950s the French navy was frustrated by the refusal of the U.S. and Royal Navies to reveal new ASW technology. The French were aware that something called LOFAR was very important, but they did not find out its meaning. That is evident in their 1956 designation of the new destroyer La Gallissonière as a 'LOFAR ship,' which meant that it used a low-frequency active sonar. In fact LOFAR was the new technology of narrow-band low-frequency passive acoustics, which made possible SOSUS and associated new tactics, as well as the new kinds of sonobuoy maritime patrol planes used to prosecute SOSUS contacts. In 1956 LOFAR was the central fact of U.S. and British ASW. The nature of LOFAR was publicly disclosed only in the 1980s, presumably because the Soviets had obtained it (perhaps through the Walker spy ring). The existence of SOSUS and its association with maritime patrol aircraft had been disclosed by Secretary of Defense Robert McNamara in the late-1960s, possibly inadvertently. As for selling the new ASW strategy, the author vividly recalls angry protests by British officers when the U.S. Navy unveiled its Maritime Strategy, which directly opposed a convoy type of ASW. They absolutely rejected any kind of offensive ASW, on the ground that it had failed in two world wars - without accepting in any way that systems like SOSUS had changed the situation (it may have been significant that it was the RAF Nimrods which prosecuted SOSUS contacts in British areas of responsibility). 
the question of what sort of escort forces the Royal Navy should build. The Chiefs of Staff produced a paper ("Global Strategy") which suggested that the international situation had been changed by growing U.S. nuclear firepower (this was before the advent of thermonuclear weapons). The big war might never break out, because no one would lightly risk nuclear devastation. The U.S. Eisenhower Administration reached similar conclusions slightly later.

Deterrence would not preclude smaller wars, such as that in Korea. Between 1952 and 1957 British defense planners, including those in the Admiralty, rethought their position, working through the implications of the new 'global strategy' - and the brutal financial consequences of trying to pursue the earlier mass-ASW escort strategy. They came to distinguish between hot war, warm war, and cold war. Hot war was a World War III; it was essential to maintain enough strategic firepower to deter it. On the other hand, it was unlikely that a World War III would look like World War II; mass ASW might not be very important. Warm war was what Soviet proxies (and others) could conduct on the Eurasian periphery. It was probably the most important application of military and naval power. Cold war was pressure without fighting. For the Royal Navy, the epitome of warm war was the Confrontation fought against Indonesia. The physical symbol of the change was the shift from special-purpose ASW frigates like Type 12 (which had some wider value thanks to its gun) to general-purpose frigates, beginning with the Tribal class (Type 81$)^{9}$

Meanwhile U.S. planners concentrated increasingly on nuclear weapons and their implications. They became more and more interested in submarine-launched missiles. The Germans had been interested in such weapons, and the U.S. Navy was already deploying them in the form of the Regulus cruise missile. Given German interest, it seemed obvious that the Soviets were working on such weapons (they were). The U.S. Navy also intermittently considered the potential of sea-launched ballistic missiles, which it began seriously developing in 1956 (we now know, but the West did not know at the time, that the Soviets launched their first such missile from a submarine in 1955). The United States was already investing heavily in means of blunting the Soviet bomber threat. The Soviets could end-run the elaborate North American air defense system using submarines. Now the U.S. Navy became more interested in what might be called strategic ASW (against missile submarines) than in protecting NATO sea communications. The developing SOSUS system was key, because at least in theory it could detect and track missile submarines before they got within range of their targets. The convoy strategy of the past would have been irrelevant, because a strategic

9 For details of changing designs, see the author's British Destroyers and Frigates: The Second World War and After (London: Chatham, 2006). The first major expression of the new deterrent-based strategy was the Global Strategy paper, a 12 June 1952 report by the Chiefs of Staff to the Defence Committee. The Chiefs of Staff reported on cuts after mobilization in a 31 October 1952 paper. Controller put the navy's case in 1954. First Sea Lord Mountbatten laid out the new strategy in a series of newsletters in UKNA, ADM 205/183. See the author's The Postwar Naval Revolution (London: Conway Maritime Press, 1986), the British programmatic sections of which were taken from Admiralty documents in the UKNA. 
submarine would spend its time trying to evade surface ships of all kinds. British naval observers were furious; it seemed that the U.S. Navy was abandoning them. ${ }^{10}$ They blamed a naive U.S. obsession on directly protecting North America.

Some in the United States saw SOSUS more as a means of warning against Soviet surprise attack than as a means of defeating a Soviet offensive against Atlantic shipping. It seemed that, on the eve of such an attack, Soviet submarines would suddenly move into war stations in the western Atlantic - where they could be detected by SOSUS. This concern in turn can be traced to studies, from 1953 onwards, which showed that a successful Soviet surprise attack could destroy the main U.S. nuclear striking force, the Strategic Air Command, on the ground. ${ }^{11}$

For Canadians, the U.S. shift was a very important development, because the United States would surely seek their assistance in this new kind of ASW - which was entirely outside the accepted NATO naval mission of protecting shipping crossing the north Atlantic and supporting possible carrier strikes against Soviet naval bases. Canada was already a partner in North American air defense. She was also encouraged to participate in operating the SOSUS system, some of whose arrays were in Canadian waters. For the British, the irony was that their more advanced strategic naval thinkers were already abandoning classic convoy ASW. They were becoming more interested in the kind of ASW needed to support task forces operating in the Third World.

The evolving British view was complicated by membership in NATO, whose agreed strategy changed much more slowly, hence remained more like that of the early1950s. During later budgetary warfare, the NATO role was used to help justify planned forces. It ensured that the Royal Navy would pay more attention to Atlantic ASW than the hot/warm/cold view might have warranted. Too, views continued to evolve, so that in the early-1960s many imagined that a limited hot war could be fought in Europe before anyone escalated to nuclear warfare. The limited hot war, and the run-up to such a war (during which NATO would mobilize in competition with the Warsaw Pact) certainly

10 See UKNA, ADM 205/103, First Sea Lord's papers for 1954.

11 When he entered office, Dwight D. Eisenhower asked for studies of the possible impact of a Soviet surprise attack. While he refused to be panicked by their rather dire conclusions, it does seem clear that many in the U.S. government took the possibility of a surprise nuclear attack seriously. It is clear from surviving U.S. documents in the Foreign Relations of the United States series that initially the North American radar system was justified not as a means of dealing with attacking Soviet bombers so much as a means of warning SAC bombers to take off. The situation changed as the automated SAGE system entered service (ironically, as the Soviets abandoned bombers in favor of ICBMs). Another irony is that the demand that the U.S. Navy automate its combat direction systems came from the 1954 Lamplight Conference on North American air defense, the idea being that automation would make it possible for ships offshore to feed their radar data directly into SAGE, then under development. The conference thought that was possible because it knew that a naval combat information automation system already existed in the form of the Canadian DATAR. The final irony is that neither DATAR nor the U.S. NTDS system ever equipped (or was even proposed for) the many radar picket ships the U.S. Navy maintained as part of the North American system. 
justified concentration on Atlantic ASW, probably to an extent beyond what many British governments would accept. The consequences of this further evolution of thinking lie outside the scope of this paper.

With the British shift away from ASW, the Royal Navy and the Royal Canadian Navy in effect parted company. The Canadians continued to specialize in ASW, although over time their view of ASW tactics and technology changed. They did not, for example, become interested in general purpose as opposed to ASW frigates. The difference showed in their view of the way frigates should operate helicopters. It turned out to be very important that their new frigates were large enough that they could be rebuilt to operate large ASW helicopters (Sea Kings) with dipping sonars. That was not possible for the new British frigates.

\section{ASW Frigates}

The shift back and forth between a general-purpose fleet and a sea control fleet did not much affect research on anti-submarine warfare, because the new generation of submarines the Germans had introduced late in World War II could attack both the fleet and merchant shipping. Both the Royal Navy and the U.S. Navy became interested in new sonars with much better search rates (achieved by scanning) and also with greater ranges (by using lower frequencies). Both methods entailed much larger sonar transducers, hence larger hulls. Both navies also became interested in longer-range weapons, the British Limbo and the U.S. Weapon Alfa, and in homing torpedoes. The most important tactical development was the anti-submarine submarine, in effect a throwback to tactics which had been effective during World War I. Since neither Australia nor Canada had submarine forces in 1945-55, for them the most important development during this period was probably the fast ASW frigate.

Without long-range standoff weapons or helicopters (and without medium-range sonar) an ASW ship had to get (and remain) close enough to keep engaging a submarine at fairly short range (each salvo had a relatively limited probability of killing the submarine, so attacks had to be cumulative). That in turn required abut a 10-knot speed advantage over a submerged submarine. The Type XXI U-boat introduced in 1945 could run at about 17 knots submerged, for a protracted period - about the sea speed of most of the escorts mass-produced during the war. The Soviets had captured Type XXIs and were expected to mass-produce them. In fact the submarine they did mass-produce, Project 613 (NATO code-named 'Whiskey') was not a clone of Type XXI, but smaller and somewhat slower; however, it presented much the same kind of problem (the near-clone of Type XXI was the later 'Zulu' [Project 611]). Until about 1952 it seemed that for some reason the Soviets had not yet begun mass production of new submarines, although they did have a large existing fleet which could be (but, surprisingly, was not) modernized. Western navies which had been desperate because they could not mass produce fast escorts were given, in effect, a breathing space during which the better wartime escorts, modernized, would be effective. Canada reinstated numerous Riverclass frigates and rebuilt most of them as the Prestonian class.

For the Royal Navy, the fast post-war frigate began with a 1945 project for a 25- 
knot frigate, which could be built in various versions. Requirements included long endurance, which in turn led the British to adopt diesel engines (the standard type also used in their post-war submarines). Existing British steam plants, which could have given the ship higher speed, did not offer sufficient endurance in the limited displacement desired (for continued production). Alternative frigate roles were anti-submarine, convoy air defense, control of shore-based aircraft operating over a convoy, and convoy flagship. The last was abandoned as too specialized. It was soon obvious that diesels could not drive a frigate fast enough for ASW, so initially the British concentrated on 23 knot antiair and aircraft direction frigates, Types 41 and 61 .

Meanwhile, work proceeded on a new generation of much more efficient steam plants, inspired by wartime problems of short range in British warships, and which also promised much higher ship speed. As these plants neared maturity, the fast ASW frigate became a more practical proposition. Thus in 1948 work began on Type 12, the prototype for which was laid down in 1952. Probably its most important characteristic was its high sea speed, 27 knots. It was designed to be armed with the new Limbo mortar and a powerful dual-purpose gun (the twin 4.5 -inch, as interim for the twin 3-inch/70 then under development) and with a self-contained twin Bofors (STAAG) aft. Type 12 had a remarkably long production career, morphing into the general-purpose Leander class by about 1960 .

British warship design manpower was limited. It was natural to use elements of the Type 41/61 (Leopard / Salisbury classes) design in the new one. Surviving documents do not say as much, but it seems obvious that the Type 12 hull was essentially that of the earlier slower ship with a bow extension which made it possible to drive efficiently at higher speed (the longer the ship, the easier it is to drive). The bow was given a fine entry for high speed, and consequently contributed only limited buoyancy. The choice of hull form limited available space aft. That was perfectly acceptable, since space aft was needed only for the ship's ASW armament: double Limbo and A/S torpedo tubes, the latter soon removed. Although the first ships lacked it, the hull was arranged to take the first British long-range scanning sonar, Type 177, whose transducer was considerably larger than the existing searchlight types.

The Royal Canadian Navy had a similar requirement, but was determined not simply to copy the British frigate design. It therefore imported a British naval constructor, who created a very different hull form to meet much the same speed, seakeeping, and weapons requirements. It seems very likely that the Canadian requirement was framed before Canada joined NATO in 1949, hence before there was a formal national requirement to revive Canadian ASW, but it is not clear to what extent that is true. The Canadian government froze sales of war-built frigates in 1948.

This St. Laurent class was armed with the same ASW mortar, but used a mix of U.S. and British sonars (the British Type 170 to control Limbo and the U.S. SQS-11 scanning sonar) and guns (eventually it had the British twin 3-inch/70 and a U.S. twin 3inch $/ 50$, which the Canadians preferred to the British STAAG). Although about the size of a Type 12, it was not merely a Canadian equivalent. In particular, it had a very different hull, designed for the desired ASW frigate performance rather than redesigned 
from a shorter slower ship. The effect of the different hull was to move the ship's superstructure forward, and thus to leave much more space aft. The Canadians were also clearly less impressed than the British with nuclear threats, so they accepted a higher superstructure.

Reportedly the British and Canadian frigates, at two ends of the design spectrum (the Canadians opted for a much fuller forebody) were the best sea-keepers of all contemporary NATO designs, the Canadian ships being considered somewhat better. The Canadian design also turned out to be more flexible. In the late-1950s, when the Royal Navy turned away from the emphasis on ASW, it became interested in a general-purpose frigate. The main changes were a better radar to provide air control capability (Type 965), and a helicopter pad aft. A fresh frigate design was considered but abandoned in favor of a modified Type 12 which became known as the Leander class. Given the way in which elements of the ship had been pushed aft, there was not enough space for a large hangar and pad; Leanders carried small Wasp helicopters. They were effectively extensions of the ship, carrying either homing torpedoes or small missiles. Eventually the Indians managed to squeeze the larger Sea King into some modified Leanders they built, but apparently the result was not entirely satisfactory.

The British also suffered some disappointments which cannot be blamed on the design of the ship. In the late-1950s they began work on an air defense missile which they hoped could simply replace the twin 4.5 -inch gun: Sea Dart. This kind of replacement proved impossible. In some Leanders the British were able to replace the gun with the Australian Ikara anti-submarine missile (the Royal Australian Navy managed to combine the gun with a helicopter [but no hangar] and Ikara and a better air search radar, at the cost of Limbo). It also proved possible to fit Type 12s and Leanders to tow the new array sonars.

The Canadians became interested in 'single-package' ASW helicopters which could independently detect submarines, using dipping sonars, and homing torpedoes. The big Sea King could fit the available space. It provided the Royal Canadian Navy with a distinctive kind of frigate-based ASW, which no other NATO navy could match. To the extent that it took a helicopter with a dipping sonar of its own to exploit improving shipboard sonar detection range (and also to exploit improving sonobuoy capabilities), it seems arguable that the stretch inadvertently built into the Canadian ships was decisive. The Canadians developed a variable-depth (towed active) sonar, which both they and the Royal Navy adopted. By all accounts it was considerably more successful than slightly later U.S. variable-depth sonars.

There was no possibility that expensive Type $12 \mathrm{~s}$ or St. Laurents could be built in the numbers envisaged in the early-1950s, so both navies sought alternatives. The British developed Type 14, a frigate with Type $12 \mathrm{ASW}$ equipment (but no 4.5 -inch gun) and half the power of a Type 12. This 'World War III corvette' was expected to cost about a fifth less than a Type 12. An attempt at an even less expensive third-rate ASW frigate was abandoned as not worthwhile. Fourteen Type 14s were built for the Royal Navy. They were completed just as it became obvious that the specialized ASW mission - the hot war mission - was much less important than the warm war mission for which the gun, and in 
future a helicopter, were so vital.

The Royal Navy also developed plans to convert the mass of existing war-built destroyers with single-purpose main guns, hence unlikely to survive the expected scale of future air attack. These Type 15 and Type 16 conversions were undertaken in fair numbers, also to be overtaken by the change in strategy in the mid-1950s.

The Royal Canadian Navy produced no equivalent to the British Type 41/61 because it was concerned with ASW from the Canadian coast to mid-ocean, where there was little air threat. The RCN did place fighters on its carriers, but they were gradually displaced by ASW aircraft. Much later it became interested in providing its frigates with better air defense, as it had to accept that they could be asked to operate closer to European waters in which there would probably be real air threats. However, because this thinking took about two decades to develop, initially the RCN was interested only in fast ASW frigates. Its decision to build new ships predated the formation of NATO, but not by much; it was slightly later than the beginning of the British Type 12 project. Moreover, when it began thinking in 1948, the RCN had access to highly-efficient U.S. steam plants which offered the sort of endurance the British could not achieve until they had their new post-war plants. Thus the Canadians had no reason to design big diesel frigates.

Because the Royal Canadian Navy's plans lagged those of the Royal Navy by a few years, it did not go as far in second-level projects. It did convert existing destroyers (as did the Royal Australian Navy), but its plans for a Canadian equivalent to Type 14, the Vancouver class, were abortive.

On the other hand, the Canadians did not adopt anything like the British national strategy. They decided to discard their carrier without replacement, and they dropped a project for a new general-purpose surface combatant armed with a Tartar surface to air missile. Without the missile, and without fighters from the carrier, the ship could not survive in the face of the increasing scale of air attack. In effect the Royal Canadian Navy made a decision to hold to the NATO ASW role. That was probably not its worst option. From the point of view of internal politics, the British shift towards the warm war role tied the Royal Navy to operations East of Suez and to replacement aircraft carriers - the cancellation of which, in the wake of the Confrontation victory, proved traumatic. The Royal Navy found itself falling back on the NATO role, subject to serious questions about its reality, when the time came to cut defense spending in 1981.

The story looks more coherent in retrospect than it did at the time, but coherence at the time was probably due to the common World War II experience of the people involved, remembering that World War II reflected something like a common empire navy. Overhanging the story of the 1945-55 period is, of course, the role of the United States and its own hopes to create something not too different from the Empire Navy envisaged by the Royal Navy since before 1914 . 